The $5^{\text {th }}$ International Conference on Family Business and Entrepreneurship

\title{
EMPLOYEE PERFORMANCE REVIEW OF SERVANT LEADERSHIP AND ORGANIZATIONAL COMMITMENT AT THE SAMAYA SEMINYAK BALI HOTEL
}

\author{
I Ketut Sirna $^{1 *}$, Ni Putu Budihari Saputri ${ }^{2}$, I Nyoman Tingkes ${ }^{3}$ \\ ${ }^{1,2,3}$ Faculty of Business, Dhyana Pura University \\ Corresponding author: sirna@undhirabali.ac.id
}

\begin{abstract}
This study aims to determine partially and simultaneously servant leadership and organizational commitment to employee performance at The Samaya Seminyak Bali. Proportional Random Sampling method, the number of samples is 51 employees. Data analysis using Validity Test, Reliability Test, Partial Correlation Analysis, Multiple Correlation Analysis, Multiple Linear Regression Analysis, Coefficient of Determination Test, the research shows that (1) servant leadership has a positive and significant effect on employee performance, with the results of regression analysis of X1 $=0.295$, (2) organizational commitment has a positive and significant effect on employee performance, with the results of regression analysis of X2 $=0.593$, (3) simultaneously servant leadership and organizational commitment have a positive and significant effect on employee performance, obtained multiple linear regression analysis of $Y=$ $12.251+0.295 X 1+0.593 X 2$, and the coefficient of determination shows $21.3 \%$. Based on these results, it can be concluded that servant leadership and organizational commitment are very influential partially and simultaneously on employee performance at The Samaya Seminyak Bali.
\end{abstract}

Keywords: Servant Leadership, Organizational Commitment and Employee Performance.

\section{Introduction}

Employee performance is one of the factors that must be considered by companies related to human resources. According to Abdullah (2014:3) performance is work performance which is the result of the implementation of work plans made by an institution carried out by leaders and employees who work in that institution, both government and companies to achieve goals.

One of the factors that are thought to affect employee performance is leadership. A leader plays an important role in an organization. Therefore, the progress of an organization also depends on the leadership figure which is reflected through the nature, methods and leadership style. As a leader who can bring and direct his subordinates to work better, which of course is liked and respected by his subordinates.

The Samaya Seminyak Bali as one of the hotels engaged in accommodation services with a high level of competition among similar hotels operating in the same field needs to improve the performance of their employees. Leadership style applied by management The Samaya Seminyak Bali, one of which is servant leadership, which is a leader willing to step in to serve and also take the initiative to help if employees experience difficulties at work.

From the results of the observations made by the author that the leadership at The Samaya Seminyak Bali hotel so far was born from the organization itself, because the management leadership pattern that comes from within the organization tends to show servant leadership characteristics, one example of which is the leadership descending directly to the division to the lowest employees to notify work targets to be achieved, where superiors provide information that employees need to do a good job,

The performance of employees at The Samaya Seminyak Bali can be seen from the guest comments of 401 
guests who have stayed in Table 1 as follows:

Table 1. Guest Comments Guests Staying at The Samaya Seminyak Bali Hotel

\begin{tabular}{|c|c|c|}
\hline Name & Address & Comment \\
\hline Yazeed Alhawiti & Saudi Arabia & $\begin{array}{l}\text { Very nice place, the staf is one of the success tools in the resort. I } \\
\text { appreciate everything done for us here and I would like to thank all } \\
\text { in Samaya for their great hospitality and the service. }\end{array}$ \\
\hline Martin Williams & UK & $\begin{array}{l}\text { Looking forward to coming here again. Greatly exceeded as } \\
\text { expectation. The villa were perfectly for us. Very noce staff, good } \\
\text { food, beachfully keep resort. }\end{array}$ \\
\hline Ala Amro & Jordan & $\begin{array}{l}\text { First, the wooden floor looks great but debries enter into feet and may } \\
\text { causer injury. Maybe made painting. Second, sinks needs more } \\
\text { attention as the water seens to drain slower than it should be. Third, } \\
\text { we enjoyed our stay to the max. we will recommended to friends and } \\
\text { family. Special thanks to kind staff and management. }\end{array}$ \\
\hline Alvin Soon & Singapore & $\begin{array}{l}\text { Paid usd } 33 \text { for airport transport but the car was very old and driver } \\
\text { pick up service was very far away. Compereed to hotel shuttle was } \\
\text { disappointing. }\end{array}$ \\
\hline Allan Kentwell & Australia & $\begin{array}{l}\text { We enjoyed our first villa } 110 \text { but did not enjoy villa } 107 \text {. Our butlers } \\
110 \text { very good. We did not see butler at } 107 \text {. The garden at } 107 \text { needs } \\
\text { to be upragraded, too many dying plants, not as good as } 110 \text {. Stay } \\
\text { have been very corteous and I loved the spa also. Thank you very } \\
\text { much. }\end{array}$ \\
\hline
\end{tabular}

Sumber : Front Office Departemen The Samaya Seminyak Bali 2020

From the guest comments above, it shows that there are several guests staying at The Samaya Seminyak Bali hotel who gave positive comments. Guests who stay feel very comfortable and happy because the service provided by the employees is very good and friendly. And there are also some guest comments that give unfavorable responses related to poor staff service and facilities. From the guest comments above, it can be said that guests are not satisfied with the services and facilities provided during their stay at The Samaya Seminyak Bali hotel.

For the above, at The Samaya Seminyak Bali hotel, commitment between leaders and employees in the company is very important because employee commitment will have a positive impact on employee attitudes and behavior in achieving company goals (Sidharta and Margaretha, 2011). Employee loyalty to the company will be low if organizational commitment is also low, thus increasing the desire to leave the company. According to Lauture et al. (2012) stated that the high organizational commitment of employees can be influenced by several factors, one of which is organizational culture. The description of the three aspects of commitment to measure employee commitment can be seen from the acceptance of organizational goals, the desire to work hard, and the desire to survive being part of the organization according to Mowday (Sopiah, 2011: 165).

Thus, from the survey results, it can be said that the commitment of employees at The Samaya Seminyak Bali hotel is a little less good. Based on the results of interviews with HRD researchers, there are still employees who do not keep their commitments, such as: there are employees who do not keep their work contracts according to the initial work agreement where employees stop working without a one month notice. In addition, there are also some employees who start to like to be late for work and leave work hours prematurely. This is the cause of the lack of employee commitment to the company. This is what causes researchers to be interested in conducting research at The Samaya Seminyak Bali.

\section{Problem Formulation}

From the background of the problem above, the formulation of the problem can be stated as follows: How is the partial and simultaneous influence between servant leadership and organizational commitment on employee performance at The Samaya Seminyak Bali Hotel? 
Aims and benefits of Research

This study aims to determine the partial and simultaneous effect of servant leadership and organizational commitment on employee performance at The Samaya Seminyak Bali Hotel.

\section{Literature Review}

\section{Understanding Employee Performance}

Performance is the result of a process that refers to and is measured over a certain period of time based on pre-determined provisions or agreements according to Edison et al (2016).

According to Mangkunegara (2011) employee performance is the result of quality work achieved by an employee in carrying out his duties in accordance with the responsibilities given to him. The work that can be achieved by a person or group of people in an organization in accordance with their respective authorities and responsibilities in order to achieve organizational goals legally, does not violate the law and is in accordance with morals and ethics according to Sinambela (2016: 481). and Factors Affecting Performance According to Wibowo (2012: 379), namely: 1). Individuals, indicated by the level of skills, competencies, individual commitments, 2). Leaders, determined by the quality of encouragement, guidance and support by managers and team leader, 3). Supporting Facilities, indicated by the existence of a work system and facilities provided by the organization, 4). Work Environment, indicated by the high level of pressure and changes in the internal and external environment, 5). Team Work, indicated by the quality of support provided given by co-workers.

Employee Performance Indicators according to Robbins (2016: 399) consist of: 1). Work Quantity is the amount produced expressed in terms such as the number of units, the number of activity cycles completed, 2). Work Quality as measured by employees' perceptions of the quality of work performed produced as well as the perfection of tasks on the skills and abilities of employees. The quality of work emphasizes the effectiveness and efficiency of employees in completing their work, 3) Depth of Knowledge is a measure to find out how far an employee or employee understands about his duties or work. An employee or employee who has knowledge about his work will be very helpful in the process of completing his work, 4). Cooperation is an important thing in a company organization, cooperation between fellow employees must go well. This is because good cooperation between employees will be very helpful in accelerating the completion of work. Good cooperation will be created by the existence of a relationship or communication that runs smoothly between fellow employees, 5). Attendance is very important in the ongoing activities in the company. The presence or absence of an employee will greatly affect the results or goals planned by the company previously, 6). Initiatives are ideas or thoughts of an employee who is trying to make updates at work, checking his work, and trying to complete his responsibilities properly.

\section{Definition of Servant Leadership}

According to Northouse (2013: 207) Servant leadership is a paradox, an approach to leadership that contradicts existing realism. Servant leadership emphasizes that leaders pay attention to the problems of their followers, empathize with them, and develop them. is leadership that serves, empowers and develops employees with humility, purity of heart, and respect for others according to Van Dierendock (2011). As for the Factors Affecting Servant Leadership, according to Hederson, et al (Deby, 2019) include: 1). Context and Culture is the culture and conditions that exist in the environment within an organization. 2). Leader Attributes is a role in the character and ability to realize servant leadership which includes emotional intelligence and moral development, 3).Followers Receptivity is where the environmental conditions are in accordance with the expectations of employees so that the realization of Servant Leadership that has a positive effect on employee performance.

Servant Leadership indicators according to Dennis (Mustikadewi, 2015) consist of: 1). Compassion, is leadership that loves with love or affection. Love is meant to do the right thing at the right time for the best reasons and decisions, 2). Empowerment, Emphasis on cooperation, namely entrusting power to others and listening to suggestions from followers, 3). Vision, is a future organizational direction that will be brought by a leader. Vision will inspire action and help shape the future, 4). Humility, namely maintaining humility by showing respect for employees and acknowledging employee contributions to the team, 5). The leader earns trust. namely the chosen people who are chosen based on an advantage that causes the leader to gain trust.

\section{Definition of Organizational Commitment}

Organizational commitment is an attitude towards the organization and a willingness to achieve everything for the sake of the organization according to Sjahruddin (2013). According to Baraba et al (2014) 
organizational success depends on employee commitment to the organization. According to Mayer and Herscovitch (Wirawan, 2013:718) defines commitment as a force that binds an individual to an action that is relevant to a certain target. Commitment is a responsive approach by an organization and job satisfaction is more a response to a specific phase of work. And Factors Affecting Organizational Commitment, According to Sopiah (Nasution, 2020) said that there are four factors that influence employee commitment to the organization, namely: 1). Personal factors, such as age, gender, education level, work experience and personality, 2). Characteristics of work, for example scope of position, challenges, conflicts, roles, level of difficulty in work, 3). Characteristics of structure, for example, size of the organization, form of organization (centralized or decentralized), presence of trade unions, 4). Work experience, affects the level of employee commitment to the organization. Employees who have only worked for a few years and employees who have worked for decades certainly have different levels of commitment within the organization.

Indicators of Organizational Commitment, according to Sopiah (2017:156) consist of: 1). Willingness of employees, namely the desire of employees to strive to achieve organizational interests, 2). Loyalty of employees, namely employees who wish to maintain their membership to continue to be a part of the organization. organization, 3). Employee pride in the organization, namely employees feel proud to have been part of the organization they follow and feel that the organization has become a part of their lives.

Research Concept Framework

The conceptual framework in this study can be seen in Figure: 2

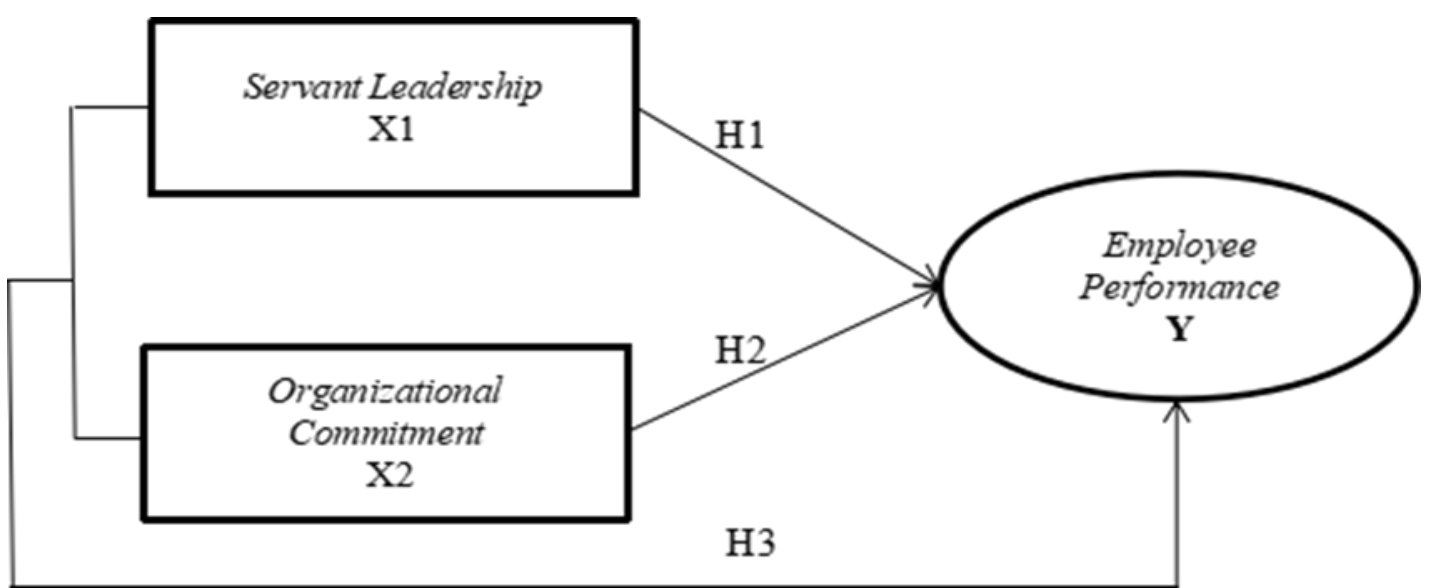

Figure 2, Research concept framework.

(Source: Sopiah 2017 and previous research)

\section{Research Method}

Identification and Definition of Operational Variables

The identification and definition of Operational Variables in the study can be explained in table 3.

possessed by the population, samples taken from the population must be truly representative (representing). Sample size is the number of samples to be taken from a population. The sampling method used in this study is Proportional Random Sampling in which sampling provides equal opportunities to each member of the population. The sample was taken randomly without regard to the existing strata in the population, this was done because the population was assumed to be homogeneous, namely permanent employees and non-permanent employees of The Samaya Seminyak Bali with a total of 104 employees. 
Table 3. Research Variables and Indicators

According to Sugiyono (2012:73) the notion of the sample is part of the number and characteristics

\begin{tabular}{|c|c|c|c|}
\hline Variable & Kode & Indicator & Indicator Description \\
\hline \multirow{6}{*}{$\begin{array}{l}\text { Employee } \\
\text { Performance } \\
\text { Robbins } \\
(2016: 399)\end{array}$} & Y 1.1 & Working Quantity & $\begin{array}{l}\text { Number of units, number of completed } \\
\text { activity cycles }\end{array}$ \\
\hline & Y 1.2 & Working Quality & $\begin{array}{l}\text { The effectiveness and efficiency of } \\
\text { employees in completing their work. }\end{array}$ \\
\hline & Y 1.3 & Depth Of Knowledge & $\begin{array}{l}\text { An employee's understanding of his duties } \\
\text { or work. }\end{array}$ \\
\hline & Y 1.4 & Cooperation & $\begin{array}{l}\text { Relationships or communication that runs } \\
\text { smoothly between fellow employees. }\end{array}$ \\
\hline & Y 1.5 & Presence & $\begin{array}{l}\text { Attendance is very influential on the results } \\
\text { or goals planned by the company. }\end{array}$ \\
\hline & Y 1.6 & Initiative & $\begin{array}{l}\text { Carry out checks on the work that has } \\
\text { become his responsibility. }\end{array}$ \\
\hline \multirow{5}{*}{$\begin{array}{l}\text { Servant } \\
\text { Leadership } \\
\text { Dennis } \\
\text { (Mustikadewi, } \\
\text { 2015) }\end{array}$} & X 1.1 & Affection & $\begin{array}{l}\text { Doing the right thing at the right time for } \\
\text { the best reasons and decisions. }\end{array}$ \\
\hline & X 1.2 & Empowerment & $\begin{array}{l}\text { Entrusting power to others and listening to } \\
\text { suggestions from followers. }\end{array}$ \\
\hline & X 1.3 & Vision & $\begin{array}{l}\text { Vision will inspire action and help shape } \\
\text { the future. }\end{array}$ \\
\hline & X 1.4 & Modesty & Show respect for employees. \\
\hline & X 1.5 & Trust & $\begin{array}{l}\text { People who are selected based on an } \\
\text { advantage. }\end{array}$ \\
\hline \multirow{3}{*}{$\begin{array}{l}\text { Organizational } \\
\text { Commitment } \\
\text { Sopiah } \\
(2017: 156)\end{array}$} & X 2.1 & Employee Willing & $\begin{array}{l}\text { Desire to strive to achieve organizational } \\
\text { goals. }\end{array}$ \\
\hline & X 2.2 & Employee Loyalty & $\begin{array}{l}\text { Maintain membership to continue to be a } \\
\text { part of the organization. }\end{array}$ \\
\hline & X 2.3 & $\begin{array}{l}\text { Employee Pride in the } \\
\text { Organization }\end{array}$ & $\begin{array}{l}\text { Employees feel proud to have been part of } \\
\text { the organization they follow. }\end{array}$ \\
\hline
\end{tabular}

The method of determining the sample size used in this study uses the Slovin formula as follows:

$$
n=\frac{N}{1+N e^{2}}
$$

Information:

$\mathrm{n}=$ Sample size

$\mathrm{N}=$ Population size

$\mathrm{e}=$ percent leeway due to tolerable or desired sampling error $=10 \%$

$n=\frac{N}{1+N e^{2}}=\frac{104}{1+104 \times(0,1)^{2}}=\frac{104}{2,04}=50,98=51$ respondent

So, the sample size used is 51 people with an error rate of $10 \%$.

\section{Descriptive Statistical Analysis}

Descriptive statistical method was used to determine the distribution of research variable data scores and the homogeneity of respondents. The homogeneity of the data was assessed based on the value and average score.

The scores of respondents' answers obtained were classified into 5 classes. The range of the largest score measurement scale is 5 and the smallest measurement score is 1 , so $5-1=4$, so the interval value is $4 / 5=$ 0.8 , then the results of respondents' answers are arranged based on the range in each class.

Partial Correlation Analysis

This analysis is used to determine whether or not there is a relationship between the dependent variable and the independent variable where one of the independent variables is considered constant.

According to Sugiyono (2017:235) partial correlation calculations can be done using the following formula: If the variable $\mathrm{X} 2$ is fixed, then the formula is used: 


$$
R_{y} \cdot x_{1} x_{2}=\frac{r_{y x 1}-r_{y x 2} \cdot r_{x 1 x 2}}{\sqrt{1-r^{2} x_{1} x_{2}}-\sqrt{1-r^{2} y x_{2}}}
$$

If the variable $\mathrm{X} 1$ is fixed, then the formula is used:

Information:

$$
R_{y} \cdot x_{2} x_{1}=\frac{r_{y x 2}-r_{y x 1} \cdot r_{x 1 x 2}}{\sqrt{1-r^{2} x_{1} x_{2}}-\sqrt{1-r^{2} y x_{1}}}
$$

$R_{y} \cdot x_{2} x_{1}$ :The correlation between the variable (X1) and the variable $(\mathrm{X} 2)$ is the same as the variable (Y).

$r_{y x 1} \quad$ :The correlation coefficient between the variable (X1) and the variable (Y).

$r_{y x 2} \quad$ :The correlation coefficient between the variable (X2) and the variable (Y).

$r_{x 1 x 2} \quad$ :The correlation coefficient between the variable (X1) and the variable (X2).

Multiple Correlation Analysis

The analytical tool used to determine whether there is a strong relationship between the independent variables and the dependent variable. The following multiple correlation test values are formulated as follows:

$\operatorname{Ry}(1,2)=\sqrt{\frac{b_{1} \sum X_{1} Y+b_{2} \sum X_{2} Y}{\sum Y^{2}}}$

Information:

Ry $(1,2)$ : Multiple correlation $Y$

b1 : Predictor coefficient of (X1)

b2 : Predictor coefficient of (X2)

$\sum X_{1} Y \quad:$ Total number X1Y

$\sum X_{2} Y \quad:$ Total number $\mathrm{X} 2 \mathrm{Y}$

$\sum Y^{2} \quad$ : Total square $Y$

Table 4. Level of Correlation Coefficient

\begin{tabular}{lc}
\hline Correlation Coefficient & Relationship level \\
\hline $0,00-0,199$ & Very low \\
$0,20-0,399$ & Low \\
$0,40-0,599$ & Currently \\
$0,60-0,799$ & Strong \\
$0,80-1,000$ & Very strong \\
\hline
\end{tabular}

Multiple Linear Regression Analysis

Source: Sugiyono (2017:231)

Multiple linear regression is a regression analysis that explains the relationship between response variables (dependent variable) and factors that affect more than one predictor (independent variable). The multiple linear regression model is described by using the following equation:

$\mathrm{Y}=\mathrm{a}+\beta 1 \mathrm{X} 1+\beta 2 \mathrm{X} 2+\mathrm{e}$

Information:

Y : Employee Performance

X1 : Servant Leadership

X2 : Organizational Commitment

a : Multiple Regression Constant

$\beta 1 X 1, \beta 2 X 2 \quad$ : Regression Coefficient

e $\quad$ : Error (other independent variables outside the regression model)

Determination Analysis

To test and find out whether this regression analysis model is feasible and how big is the relationship between the independent variables and the dependent variable. According to Sugiyono (2016: 286) it can be calculated by the formula:

$\mathrm{D}: R^{2} \times 100 \%$

Information:

D : Coefficient of Determination

$\mathrm{R}$ : Multiple Correlation Coefficient 


\section{Discussion}

The results of research at The Samaya Seminyak Bali hotel can be described as follows:

In the following discussion, the data processing used to determine the effect of servant leadership (X1) and organizational commitment (X2) on employee performance (Y) is to use the SPSS 20.0 for Windows program, which can be seen in Table 4.1 below:

Multiple Linear Regression Analysis

Multiple Linear Regression Analysis can be shown in table 4.1. which is the result of statistical analysis that shows the partial and simultaneous influence between Servant Leadership (X1), Organizational Commitment (X2), and Employee Performance (Y).

Table 5. Analysis Between Servant Leadership, Organizational Commitment, Employee Performance

\begin{tabular}{|c|c|c|c|c|c|c|}
\hline Dependent Variable & Independent Variable & r (Partial) & R (Multiple) & $\mathrm{b}$ & $t$ count & Sig. \\
\hline \multirow[t]{2}{*}{$\begin{array}{l}\text { Employee } \\
\text { Performance(Y) }\end{array}$} & $\begin{array}{l}\text { Servant Leadership } \\
\text { (X1) }\end{array}$ & 0,281 & 0,495 & 0,295 & 2,025 & 0,048 \\
\hline & $\begin{array}{l}\text { Organizational } \\
\text { Commitment (X2) }\end{array}$ & 0,398 & & 0,593 & 3,010 & 0,004 \\
\hline Constant & $=12,251$ & & & & & \\
\hline $\begin{array}{l}\text { Regression Equation } Y \\
\text { t table }(0,10 ; 48)\end{array}$ & $\begin{array}{l}=12,251+0,295 \\
=1,29\end{array}$ & $\mathrm{X} 1+0,593 \mathrm{X} 2$ & & & & \\
\hline F count & $=7,780$ & & & & & \\
\hline F table $(0,10 ; 2 ; 48)$ & $=2,42$ & & & & & \\
\hline Sig. F & $=0,001$ & & & & & \\
\hline $\mathrm{D}$ & $=0,213$ & & & & & \\
\hline
\end{tabular}

Source: Appendix 5

\section{Multiple Regression Analysis}

This analysis is used to determine the simultaneous effect of organizational justice, employee empowerment, and organizational support on employee job satisfaction at The Samaya Seminyak Bali using multiple linear regression analysis with the following model:

$$
\mathrm{Y}=\mathrm{a}+\beta 1 \mathrm{X} 1+\beta 2 \mathrm{X} 2+\mathrm{e}
$$

Based on table 4.1, the following multiple linear regression equation is obtained:

$\mathrm{Y}=12,251+0,295 \mathrm{X} 1+0,593 \mathrm{X} 2$ The multiple linear regression equation can be explained as follows:

$=12,251$ means that if the value of the direct evidence variable, Servant Leadership, Organizational Commitment is equal to zero or has not changed, the employee's performance will have a value of 12.251. b1 $=-0.295$ means that every increase in the direct evidence variable (X1) at The Samaya Seminyak Bali, each additional 1 unit of direct evidence (X1) will be accompanied by an increase in employee performance of 0.295 with the assumption that direct evidence of organizational commitment (X2) is the same constant or not changing.

$\mathrm{b} 2=0.593$ means that every increase in the Organizational Commitment variable (X2) at The Samaya Seminyak Bali, every additional 1 unit of direct evidence (X2) will be accompanied by an increase in employee performance of 0.593 with the assumption that direct evidence of Servant Leadership (X1) is equal to constant or unchanged.

Based on the multiple linear regression equation, it shows that direct evidence, Servant Leadership, Organizational Commitment both have an effect on employee performance at The Samaya Seminyak Bali.

\section{Multiple Determination Analysis}

This analysis is used to determine the contribution of servant leadership and organizational commitment simultaneously to employee performance. Expressed in percentage, with the formula D = R2 x 100\%. Based on the results of statistical analysis in Table 4.1, the coefficient of determination is 0.213 or $21.3 \%$. This shows that servant leadership and organizational commitment simultaneously contribute to the ups and downs of employee performance at The Samaya Seminyak Bali by $21.3 \%$ and $78.7 \%$ due to other factors not discussed in this study. 


\section{Conclusion}

From the results of the analysis described above in this study, some conclusions can be drawn as follows: 1) There is a positive and significant influence partially servant leadership on employee performance at The Samaya Seminyak Bali. As evidenced by the regression results of 0.295 , t.count $=2.025$ is greater than t.table $=1.29$ with a significance level of 0.048 which fulfills the provisions of significance $<0.050$. This means that the better servant leadership given to employees, the employee's performance will increase.

2) There is a positive and significant influence partially organizational commitment on employee performance at The Samaya Seminyak Bali. As evidenced by the regression results of 0.593, t.count $=$ 3.010 is greater than t.table $=1.29$ with a significance level of 0.004 which meets the provisions of significance $<0.050$. This means that the better the organizational commitment given to employees, the employee's performance will increase.

3) There is a simultaneous positive and significant influence between servant leadership and organizational commitment on employee performance at The Samaya Seminyak Bali. It is proven from the results of multiple linear regression of $\mathrm{Y}=12,251+0,295 \mathrm{X} 1+0,593 \mathrm{X} 2$, and strengthened by the results of $\mathrm{f}$.count $=$ 7,780 compared to the value of f.table $=2,42$ with a significance level of 0.001 which fulfills the significance requirement of $<0.050$. and the result of the coefficient of determination is $\mathrm{D}=21.3 \%$. This means that the better the servant leadership and organizational commitment, the higher the employee's performance.

\section{Suggestions}

From the results of the research that has been done, suggestions can be given to management, which can be considered in improving employee performance, namely:

1) On the employee performance variable, with indicators of work quality, it is suggested that the management should provide training on the application of operational standards (SOP) in addition to that the management needs to pay attention to the work environment to employees and ensure that employees are working effectively and efficiently so as to improve their performance.

2) On the servant leadership variable, on the Humility indicator it can be suggested that the management and superiors should give appreciation and enthusiasm to their employees, if there are employees who make mistakes they should not be shouted at, it is better to give advice so that in the future they are more careful while working, thus will make employees more confident in their work and can improve their performance. 3) On the organizational commitment variable, with the Employee Loyalty indicator, suggestions can be given, preferably the management needs to appreciate the efforts of employees who really work well, and are given the opportunity to transfer or change positions or provide rewards such as the best employee award and other forms to improve even better performance.

\section{References}

Abdullah. 2014. Management and Employee Performance Evaluation. Yogyakarta : Aswaja Pressindo.

Arsiyati. 2013. The Effect of Organizational Commitment, Job Satisfaction and Job Stress on Employee Performance at AJB Bumi Putra Ngawi branch. Scientific Journal of STKIP PGRI Ngawi, 11(1), $87-95$.

Astohar \& Totalwin. 2012. Servant Leadership (Servant Leadership) As A Leadership Style For Organizational Progress.

Baraba, Utami \& Wijayanti, 2014. The Effect of Organizational Commitment and Work Environment on Job Satisfaction of Muhammadyah University Purworejo Employees with Self-Confidence as a Moderating Variable. Journal and Business Segment, Vol.10, No.1, pp.63 - 66.

Dharmanegara. 2013. Effect of Spiritual Intelligence and Asta Brata Leadership The Culture of Tri Hita Karana and Employment Performance. IOSR Journal of Business and Management (IOSR-JBM), II (2), 05-12.

Dierendonck, D.V. 2011. Servant Leadership: A Review and Synthesis. Journal of Management, 37(4), 1228-1261.

Edison, Emron, Yohny Anwar, and Imas Komariyah. 2016. Human Resource Management. First Edition. Bandung: Alphabeta.

Ghozali, I. 2011. Application of Multivariate Analysis With IBM SPSS Program 17. Fifth Edition. Diponegoro University Publisher. Semarang.

Harwiki, W. (2015). The Impact of Servant Leadership on Organization Culture, Organizational Commitment, Organizational Citizenship Behavior (OCB) and Employee Performance in Women Cooperatives. Social and Behavioral Sciences, 219,283-290. 
Hasibuan, Malay S.P. 2011. Human Resource Management. Jakarta: Earth Literacy.

Hidayat. 2013. The Effect of Leadership on Communication, Job Satisfaction, and Organizational Commitment in the Banking Industry. So the Social Humanities Series, 17(1), 19-32.

Lauture, R., Amewokunu, Y., Lewis, S., Lawson, B., \& Assion. 2012. Impact Of Culture On The Organizational Commitment Of Public-Sector Employees In Haiti. International Business and Economics Research Journal,11(3), 331-342.

Liden, R. C., Wayne, S. J., Liao, C., \& Meuser, J. D. 2014. Servant Leadership \& Serving Culture. Academy of Management Journal. 57(5), pp 1434-1452.

Mangkunegara, A. A. 2011. Human Resource Management for Companies. Bandung: Youth Rosda Karya.

Meuser, J.D., Liden, R. C., Wayne, S. J., \& Henderson, D. J. 2011. Is Servant Leadership Always a Good Thing? The Moderating Influence of Servant Leadership Prototype. Paper presented at the annual meeting of the Academy of Management, San Antonio, Texas.

Mustikadewi. 2015. The Influence of Servant Leadership and Job Satisfaction on Organizational Citizenship Behavior (OCB) of 2-Star Hotel Employees in Yogyakarta. Yogyakarta State University Management Thesis. pp:1-144

Nasution. 2020. The Effect of Organizational Commitment and Authentic Leadership on Employee Performance with Job Satisfaction as an Intervening Variable at Pt Combiphar Yoyakarta.

Northouse. 2016. Leadership: Theory and Practice. Sixth Printing. Jakarta: Index.

Poly. 2011. Strategic Leadership; Lessons from Ancient Greece to Bangladesh. Makassar: The Identity of Hasanuddin University.

Priansa. 2014. Human Resources Design and Development. Alphabet. Bandung.

Purwandari. 2016. The Effect of Servant Leadership and Organizational Commitment on Employee Performance (Study on Child Development Sponsor of the Compassionn Indonesia ClusterDIY Program).

Robbins, Stephens. P. 2016. Organizational Behavior. Jakarta: King Grafindo Persada

Sapengga, S. E. 2016. The Effect of Servant Leadership on Employee Performance at Pt. Leaf Kencana Sakti Mojokerto, 4(1), 645-650.

Sedarmayanti. 2014. Human Resource Management. Bandung: Refika Aditama.

Sidharta, N., \& Margaretha, M. 2011. Impact of Organizational Commitment and Job Satisfaction on Turnover Intention: Empirical Study on Operators at a Garment Company in Cimahi. Journal of Management,10(22), 129-142.

Sinambela, Lijan, Poltak. 2016. Human Resource Management. Jakarta: PT. Earth Literature.

Sjahruddin, H. 2013. Organizational Justice, Organizational Commitment and Trust in Manager as predictor of Organizational Citizenship Behavior. Interdisciplinary Journal Of Contemporary Research In Business, Vol.6, No.12, pp.133-42.

Sopiah. 2017. Organizational Behavior. Yogyakarta : Andi Offset.

Sugiyono. 2017. Quantitative, Qualitative, and R\&D Research Methods. Bandung: Alphabeta.

Suwanto \& Priansa. 2016. HR Management in Public and Business Organizations. Fifth Printing. Bandung: Alphabeta.

Syauta, J. H., Troena, E. A., Setiawan, M., \& Solimun. 2012. The Influence of Organizational Culture, Organizational Commitment to Job Satisfaction and Employee Performance (Study at Municipal Waterworks of Jayapura, Papua Indonesia). 1(1), 69-76.

Titisari, P. 2014. The Role of Organizational Citizenship Behavior (OCB) in Improving Employee Performance. Jakarta: Motra Wacana Media.

Main, I.G.B.R. 2012. Tourism \& Hospitality Research Methodology. Yogyakarta: CV Andi OFFSET. 